\title{
The Problem of Religious Tolerance in Kazakhstan: Past and Present
}

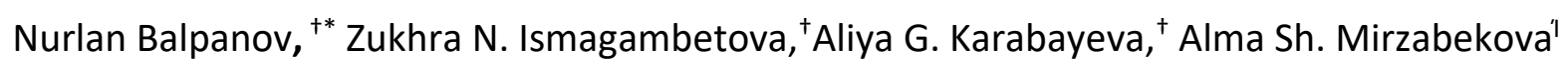
and Shamshiya S. Rysbekova ${ }^{\dagger}$

\section{Abstract}

The problem of the religious tolerance culture that helps to preserve socio-political stability in the society has become a significant theoretical and practical research problem. In the paper, the authors analyse the activities of some religious organisations in Kazakhstan trying to identify the ways of forming a culture of religious tolerance. They focus on the role of Islam, Orthodox Christianity, and Catholicism in the context of interfaith dialogue and assess the experience of preserving interethnic and interconfessional relations.

The authors argue that tolerance in a multi-ethnic society implies not only recognition of the existing ethno cultural, religious, and confessional differences within the community but also the awareness of the "unity in diversity." The latter helps to prevent the existing ethno cultural differences from the institutionalised dominance. The authors also note that the common civic identity ensures the "unity in diversity" in the Republic of Kazakhstan.

Keywords: Religious Tolerance, Multi-Ethnic Society, Ethno Politics, Hanafi Madhhab, Intercultural, Inter-language tolerance, Kazakhstan

\footnotetext{
${ }^{+}$Al-Farabi Kazakh National University, 71 Al-Farabi av., Almaty 050040 Kazakhstan, Email: 902570@mail.ru

${ }^{*}$ Corresponding Author

'Karaganda State Medical University, 40 Gogol' av., Karagandy 401000 Kazakhstan

(C)2018 Balpanov et al. This is an Open Access article distributed under the terms of the Creative Commons Attribution License (http://creativecommons.org/licenses/by/2.0), which permits unrestricted use, distribution, and reproduction in any medium, provided the original work is properly cited.
} 


\section{Introduction}

The problem of the culture of religious tolerance together with the issue of preserving the socio-political stability of society has currently emerged as an important theoretical and practical research topic. The contemporary world reckons that the culture of respect and tolerance is a condition for the survival of nations and states.

In this research, the authors define 'culture' as a phenomenon that includes an intercultural communication process and intercultural dialogue that form the mutual understanding and mutual respect of different cultures, religions, and values (Hall, 1990). This culture is still under formation; it has been developing gradually and painfully throughout the millennia, which has been engulfed with wars, conflicts, and crises of different types. Nowadays, the complex socio-political processes that take place in the world show that the only platform that can unite various ethnic groups, races, social strata, and interests for peaceful coexistence could be a tolerance that allows people to work on the democratic re-organisation of the world (Zolotukhin, 2006).

The modern society demonstrates the ambivalent characteristics. On the one hand, it requires the tolerant attitude to alternative ideological programs, but on the other, it manifests social, political, and cultural intolerance in various communities. Religious and interreligious differences are often declared as the cause of such attitude. The study of the destructive or constructive influence of these trends on society becomes an urgent issue nowadays (Gabitov et al., 2015; Sultangaliyeva, 2013). That is why the problem of religious tolerance has become one of the most actively discussed matters in the contemporary world.

In our research, we would like to demonstrate that religious tolerance is a complex phenomenon of public life when ideological and socio-psychological attitudes allow the valid coexistence of multiple religious traditions. For this reason, firstly, we present some historical aspects of the tolerance phenomenon formation. Then we will characterise the activities of Islam, Christian Orthodox and Catholic Church in promoting the interfaith dialogue, assessing the experience of preserving interethnic and interreligious relations. Finally, we will focus on the concept of tolerance and make conclusions.

\section{Historical Aspects of Tolerance}

Religious tolerance is the topic that undergoes its study and development for decades. Different prominent scholars around the world described various aspects of this phenomenon. The discussion of tolerance includes different approaches and understandings. Thus, Herbert Marcuse believed that tolerance is a false value in the modern liberal society. Some specific conditions are necessary for the genuine tolerance. Among them, the philosopher identified the developed independent thinking, the humaneness of the community around and the rejection of the violent way of decisionmaking (Marcuse, 2011).

Theodor W. Adorno followed the Marcuse lead and believed that the modern society of the twentieth century produces authoritarian individuals incapable of tolerance. According to Adorno, such people possess the following intolerant features: conventionalism, authoritarian servility, authoritarian aggression, rejection of everything subjective, superstition and stereotypes, power thinking and a cult of power, destructiveness and cynicism, predisposition to believe in dreary and dangerous processes that are going on in the world (Adorno, 2001, p. 52).

Another theorist of the Frankfurt school, J. Habermas (Habermas, 2006) believed that tolerance should be based on mutual recognition of particular rules of behaviour. As long as such regulations are established through authoritarian means (one-sided), the tolerant attitude retains the shameful spot of arbitrary exclusion (Habermas, 2006, p. 46).

As for religious tolerance, Habermas considers it as a tolerance between representatives of different faith traditions. In his opinion, the 
effective interaction between representatives of different religions is ensured by the cognitive ability to hold on to one's opinion without any emotionally negative feelings towards a different point of view. For Habermas, tolerance means an unbiased attitude towards people of a different faith and an ability to distance from the disagreement that remains on a cognitive level (Habermas, 2006, p. 47).

Another representative of the liberal tradition of tolerance, Peter Nicholson in his fundamental paper Tolerance as a Moral Ideal (Nicholson, 1985) defines tolerance as a relationship based on six characteristics: 1 ) the presence of a deviation; 2) non-triviality, moral importance of this deviation; 3) the ethical disagreement of the subject of tolerance with this deviation; 4) the power that the subject of tolerance possesses to different impacts on this deviation; 5) non-repudiation, that is, the refusal to use this very force; 6) the goodness of tolerance as a type of relationships (Nicholson 1985, p. 160). Thus, according to Nicholson, a person can be called tolerant if he or she refuses to use force to influence the existence of a morally unacceptable deviation. More importantly, such a refusal is recognised as morally right, that is, due action (Nicholson, 1985).

The British scholar, Susan Mendus in her book Tolerance and the Limits of Liberalism (Mendus, 1989) and the British philosopher Bernard Williams in his works (Williams, 2000; Williams, 1996) mention the logical paradox of tolerance. This paradox creates difficulties in the practical application of this concept to the phenomena of social life such as drug addiction or paedophilia, for example. The challenge lies in understanding tolerance as an instrumental value. In this case, tolerance is considered not as a goal, but as a means, as a minimal requirement for social relations. Only a tolerant environment can help to disclose the real potential of human being and society completely (Williams, 2000; Williams, 1996).

In contrast, Claude Lévi-Strauss in his book, Race and History (Lévi-Strauss, 2000) substantiates the idea of intercultural dialogue, defines the uniqueness and diversity of cultures as the need for the interconnection of cultural diversity and historical progress. For LéviStrauss, the world civilisation can only be a coalition of traditions on a world scale, and each culture preserves its identity. He mentioned that tolerance is not a contemplative position but a progressive attitude that consists of assuming, understanding and advancing of what wants to exist (Lévi-Strauss 2000, p. 335).

Michael Walzer in his book On Tolerance (Walzer, 2000) proceeds from the recognition of cultural diversity, religious differences, and differences in lifestyle (Walzer, 2000, p. 24). Walzer formulates an excellent aphorism that tolerance makes the existence of differences possible while differences necessitate tolerance (Walzer, 2000, p. 24). Tolerance, in the views of Walzer, are a whole range of relationships: 1) a humble acceptance for the sake of peace; 2) a passive and relaxed indifference; 3 ) the principle recognition that the other has rights, even if he uses them in an unattractive way; 4) openness to others along with curiosity; and 5) approval of the difference. Tolerance is possible only in case of peaceful coexistence of groups of people with different historical heritage, cultures, and identities. In the view of this diversity, Walzer points out those practical matters of tolerance, such as religious issues, education, and gender must be addressed differently in different political and cultural contexts (Walzer, 2000).

Therefore, the Western scholarly tradition still does not have such a theory of tolerance that could satisfy the needs of a modern multicultural, pluralistic society and globalisation.

Kazakh researchers also understand the importance of keeping stability and developing tolerance in interethnic and interconfessional relations (Kadyrzhanov, 2013). Therefore, they underline the role of religion and faith in maintaining peaceful coexistence among Kazakhstani people. Kazakh scholars pay particular attention to the development of the "peace culture" concept. The tolerance issues 
in Kazakhstan society continues to be discussed by many scholars (Nysanbayev, 2007; Mansurova, 2015; Kadyrzhanov, 2013 and many others). Different social and philosophical aspects of tolerance in the context of intercultural communication are often discussed on the academic level, but the issue of religious tolerance remains untouched.

It should be mentioned that the formation of religious tolerance as a unique moral and spiritual value went through a long way of historical development. A legislative act of Emperor Constantine is considered as the first socio-historic milestone in this realm. It legitimised the Christian Church prohibiting persecution of Christians in the Roman Empire. The next step in the development of tolerance was taken during the Enlightenment (Marshall \& Locke, 2006; Fitzpatrick, 2006).

The period of the 18th - 20th centuries marks the other stage of the development of the phenomenon. During that time, millions of people assumed that the right to confess a religion and satisfy their religious needs is among basic fundamental rights, which is crucial for the healthy development of a civilisation, state, civil society, and culture. It was reinforced by The Universal Declaration of Human Rights that was adopted by the UN General Assembly in Paris on 10th December 1948 as a universal standard of achievement for all peoples and all nations, setting out, for the first time, fundamental human rights to be universally protected. The document includes the statement on religious freedom that lists freedom to change one's religion or belief, and freedom, either alone or in community with others and in public or private, to manifest one's religion or belief in teaching, practice, worship, and observance (article 18) (The United Nations ). ${ }^{1}$

Thus, it can be argued that the issue of religious tolerance has a long and complicated history and the academic path to walk. Many scholars agree that tolerance is manifested in particular

\footnotetext{
${ }^{1}$ The United Nations Official Website, http://www.un.org/en/universal-declaration-humanrights (accessed 18 March 2018)
}

actions of individuals, social structures, and governmental institutions (Sultangaliyeva, 2013). Nowadays, religious tolerance can be understood as a universal value and social norm of civil society. It expresses the right of individuals to have a religious affiliation and publically demonstrate it.

As we can see, tolerance remains one of the most argued values of modern society. However, this contradiction does not diminish its significance but instead reflects the extreme complexity of the world in which modern people have to live.

\section{Research Methods}

The primary research methods that were used to collect the facts and materials for the paper are the method of inquiry, personal interview, comparative analysis, and narration.

For conducting individual interviews, we had selected eight ministers of religious organisations. Three each from Islamic imams and Orthodox priest and two from Catholic prelates. In the process of interviewing, our doctoral student collected the information about the work of religious organisations from these ministers. The survey included ten questions that were prepared in advance for the interviews.

The target group for the sociological survey included 80 people from among representatives of religious organisations located in Almaty (see, Figure 1 for an overview of the Central Mosque in Almaty) and Pavlodar. The respondents were given two types of a questionnaire with twenty questions in each. The first questionnaire contained one questionfilter (a closed question), four question-filter, ten essential questions of the survey), four semi-closed questions, and one dichotomous question.

The second questionnaire included questionsmenus and scale questions. Among these questions, we singled out alternative ones to receive more clear answers to the inquiry about the measures taken to preserve ethnic and confessional relations in the society. All the raised questions were in the alternative form. 
The processing of the questionnaires included assigning scores to each question and using the method of graphical quantity recording.

\section{The Ethnic and Religious Picture of Independent Kazakhstan}

The rapid process of modernisation of Kazakhstan society at the turn of the 20th and 21st centuries launched the process of religious revival that identified particular problems that Kazakhstan did not face before. A multiconfessional space was formed within the country that included all currents of Islam and Christianity, and some new religious movements. Among them were pseudoreligious organisations of destructive and totalitarian nature that facilitated the penetration of religious extremism. Therefore, the quest for an adequate cultural and social model for the preservation of the socio-political and economic stability in the society turned out to be one of the most critical social tasks.

That task was not an easy one simply for two reasons. The first one is the ethno cultural context. Modern Kazakhstan is a state, in which representatives of more than a hundred ethnic groups live keeping and manifesting their cultural traditions and religious beliefs.

Among them are the Czechs, the Poles, the Iranians, the Russians, the Turks, the Koreans, the Kurds, the Chechens and many others (Table 1).

\section{Table 1: Ethnic Structure of Kazakhstan Population}

\begin{tabular}{|c|c|c|}
\hline Ethnic Group & $\begin{array}{l}\text { Total Population of Kazakhstan as of } 1 \text { March } \\
2016\end{array}$ & In percentage \\
\hline Total & $17,458,500$ & 100 \\
\hline Kazakhs & $11,200,000$ & 65.52 \\
\hline Russians & $3,700,000$ & 21.47 \\
\hline Uzbeks & 521,000 & 3.04 \\
\hline Ukranians & 301,346 & 1.76 \\
\hline Uighurs & 246,777 & 1.44 \\
\hline Tatars & 203,108 & 1.18 \\
\hline Germans & 181,928 & 1.06 \\
\hline Koreans & 105,400 & 0.61 \\
\hline Turks & 104,792 & 0.61 \\
\hline Azerbaijanis & 98,646 & 0.57 \\
\hline Dungans & 62,029 & 0.36 \\
\hline Belarusians & 60,295 & 0.35 \\
\hline Kurds & 42,312 & 0.25 \\
\hline Tajiks & 42,143 & 0.25 \\
\hline Poles & 32,661 & 0.19 \\
\hline Chechens & 32,252 & 0.19 \\
\hline Kyrgyz & 29,803 & 0.17 \\
\hline Bashkirs & 16,983 & 0.10 \\
\hline Ingushes & 15,607 & 0.09 \\
\hline Moldovans & 14,083 & 0.8 \\
\hline Greeks & 8,819 & 0.05 \\
\hline Mordvas & 6,855 & 0.04 \\
\hline Chuvashes & 6,741 & 0.04 \\
\hline Jews & 3,485 & 0.02 \\
\hline Others & 97,386 & 0.57 \\
\hline
\end{tabular}

Source: Ministry of National Economy of the Republic of Kazakhstan,

http://stat.gov.kz/faces/publicationsPage/publicationsOper/homeNumbersPopulation/publBullS14-

2016?_afrLoop=1972794742117533\#\%40\%3F_afrLoop\%3D1972794742117533\%26_adf.ctrl-state\%3D17glwssppt_84 
Such a multi-ethnic situation requires a strong presence of the idea of solidarity in the society as the central condition for peaceful coexistence. Only in the context of mutual tolerance, the preservation of ethnic culture and identity, as well as the revival of indigenous beliefs could be possible (Abdakimov, 2009; Ismagambetov \& Karabayeva, 2015).

The second reason relates to the challenges of forming a legal framework. Some new laws were issued to help in the formation of the tolerance climate in the society. Thus, according to the legislation of the Republic of
Kazakhstan- On Religious Activities and Religious Associations state and religion are separated, and no any religious denomination can become the state religion. However, the adherents of religion have a right to form groups and meet for satisfying their spiritual needs.

It is well known that the religious organisations have their structural and administrative systems as well as norms and values that their members adhere to. Thus, they could be called a unique form of a social organisation.

\section{Table 2: Religious Organisations in Kazakhstan}

\begin{tabular}{ll} 
Religious Affiliation & Number of Organisations \\
\hline Islam & 2334 \\
\hline Protestant Christianity & 1181 \\
\hline Orthodox Christianity & 282 \\
\hline Catholic Christianity & 83 \\
\hline Jews & 27 \\
\hline Non-traditional and others & 79
\end{tabular}

Source: Muratbekov, 2015: 5

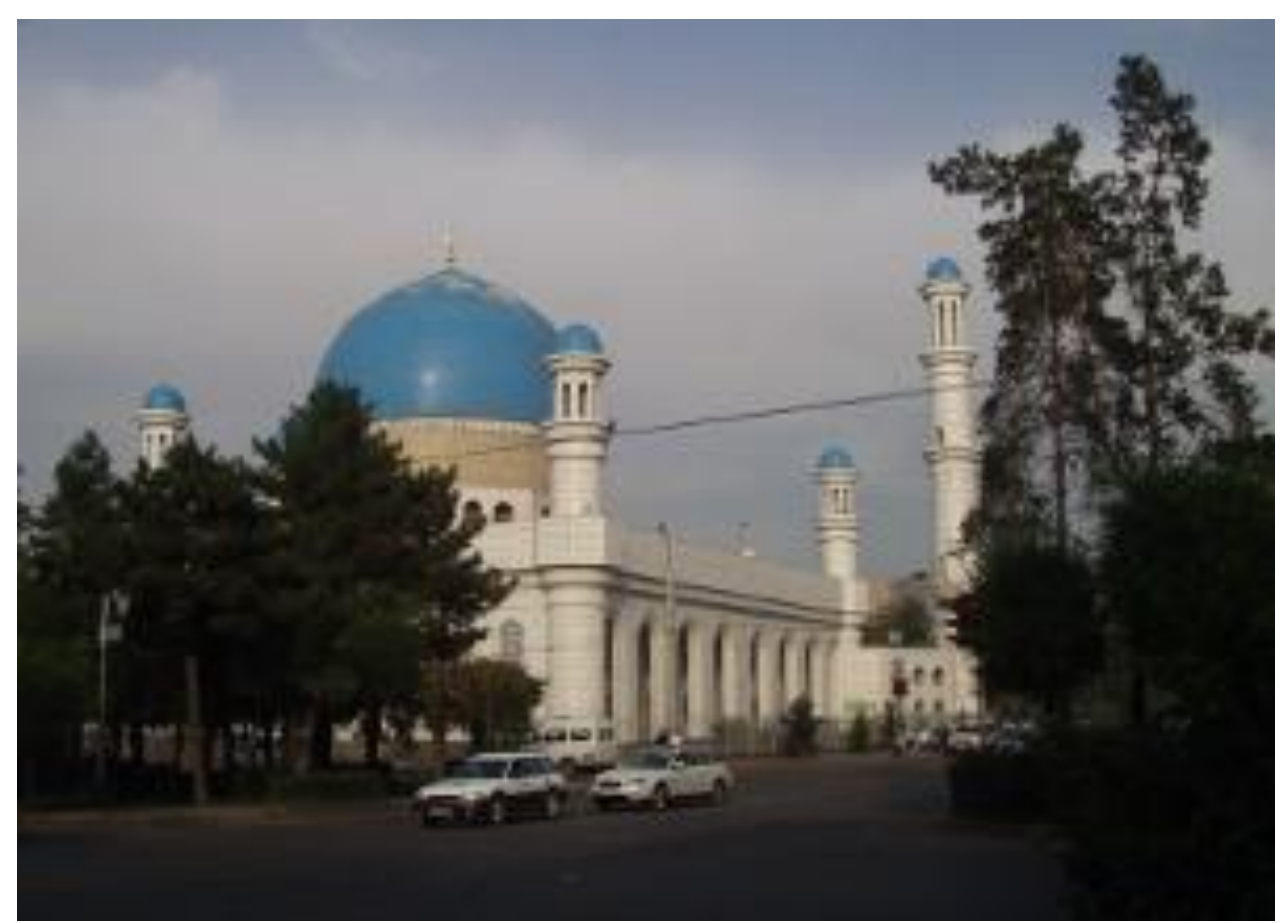

Figure 1: The Central Mosque in Almaty

\section{Source: Courtesy of the Authors}

According to the data of the Committee for Republic of Kazakhstan, as of January 1, 2008, Religious Affairs of the Ministry of Justice of the there were 4,001 religious associations and 
groups (Table 2). Out of that number 2,337 belongs to Islamic faith tradition (Sunni - 2324, Shi'a - 4, Ahmadiy - 4).

The Orthodox religious associations and groups include 281 organisations, of which the Russian Orthodox churches are 272; the Old Belief churches are 7. The Catholic congregation has 82 organisations, of which the Roman Catholic churches are 78, and the Greek Catholic churches are four.

Protestant Christianity has 1,189 religious organisations, of which traditional Protestant groups are 646, Pentecostal churches are 53, Presbyterian churches are 215, and untraditional Protestant churches are 275. Buddhist faith is represented by four organisations, which include one Tibetan Buddhist Centre and three Won-Buddhism Centres. The Jewish community has 27 synagogues. Non-traditional religions make up 50 organisations, as for charitable, religious funds and other societies, they count 31 associations.

Nevertheless, the legislation of Kazakhstan prohibits formation and activity of the religious parties or organisations that aim the establishing of the state religion, incitement of religious enmity or discord, and propagate violence and other illegal actions (Abdakimov 2009; Ismagambetov \& Karabayeva, 2015, The Official Website of the Spiritual Administration of Muslims of Kazakhstan; Religious Associations in the Republic of Kazakhstan, 2012).

To promote the multiethnic and multireligious tolerance, the unprecedented event took place in Astana in September 2003. The Congress of Leaders of World and Traditional Religions was held there. The representatives of Islam, Christianity, Judaism, Shintoism, Hinduism, and Buddhism attended it. This Congress became a tradition and now takes place every three years (Religious Associations in the Republic of Kazakhstan, 2012).

It demonstrates the desire of the state to promote mutual recognition of religions that could allow overcoming confessional differences and developing a unique formula for national unity and reconciliation of all people regardless of their faith and cultural identity.

Historically, Kazakhstan knew the prepotency of two religious traditions: the Sunni Islam of Hanafi madhhab and Orthodox Christianity. The majority of believers (95\%) in the country are representatives of these two religions. The remaining $5 \%$ are members of other faith traditions (Religious Associations in the Republic of Kazakhstan, 2012). The Hanafi madhhab is known for its ability for cultural adaptation and quickly found the way to the spiritual life of Kazakh people. It is known as the most liberal school in Islam, the foundation of which go back to the ideas of tolerance presented in the Qur'an and the Sunnah. The Qur'anic words call for tolerance towards other people: "The act of kindness can't be compared with the deed of evil. Pay (for the evil) by kindness - and that who has been your enemy will become your closest friend" (Surah, 41: 34). Freedom of religion is one of the fundamental human rights declared in the Qur'an (Surah, 2: 265). People are not able to have the fullness of life if their spiritual life experiences oppression (The Holy Qur'an).

Islam proclaims high moral values of peace and fraternity; Muslims protected even the pagans. The Qur'an says: "If one of the pagans comes and asks for the protection from murderers, be his protector until he hears the message of Allah, and if he doesn't come to believe, accompany him to a safe place" (Surah, 9:9) (The Holy Qur'an). ${ }^{2}$

In Kazakhstan, the so-called traditional Islam is represented by the Spiritual Administration of Muslims of Kazakhstan (SAMK or muftiyat) guided by the principles of religious tolerance in its work. It has a status of the Republican Islamic Association with the established branches all over the country. The SAMK obtained its independent status in 1990, even before the proclamation of the independence

\footnotetext{
${ }^{2}$ The Official Website of the Spiritual Administration of Muslims of Kazakhstan
} 
of Kazakhstan. Until then, from 1941, the Islamic community of the country was a part of the Spiritual Administration of Muslims of Central Asia and Kazakhstan. The principal task of the muftiyat is to preserve religious tolerance and conduct the spiritual education of Muslims.

The SAMK actively participates in organising and holding the Congresses of Leaders of World and Traditional Religions in Astana. It carries different public and educational activities, publishes newspapers and magazines, and has an official website. In February 2015, the First Forum of Imams of Kazakhstan was held where the following key documents were unanimously adopted: The Platform of Muslims of Kazakhstan, Ethics of a Minister of the Spiritual Administration of Muslims of Kazakhstan, The Personal Image of an Imam, and The Personal image of a Muslim.

The other type of the muftiyat's activity is organising scientific conferences, forums, and seminars on interreligious dialogue. The central objective of the SAMK forum is the education of Muslims in the country on practicing integrity, respecting the secular foundations of the state, preserving the unity of the Muslim community, promoting peaceful coexistence with other religions, contributing to the preservation of interethnic and interconfessional stability in the country (Duluman).

The muftiyat takes an active part in restoring historical and cultural monuments and mosques, as well as in building new places of worship. Currently, there are 2507 mosques in Kazakhstan and Muslims conduct some charity events called The Mercy Fairs to strengthen stability and tolerance in Kazakhstan society (Press-tsentr DUMK po Taldykorganskomu region).

The SAMK carries out an important task of preserving religious and ethnic identity, principles and norms of the traditional Islam of Kazakhs, and fostering the idea of peaceful coexistence with other denominations. This task also includes resistance to the radicalisation of Islamic teaching, the opposition to fundamentalists' ideas and propaganda, the ideological struggle with religious extremism and terrorism, the spiritual work among the believers for promoting the principles of solidarity, socio-political stability, and preservation of the cultural identity of Kazakhs.

The second leading religious player in the process of the formation of religious tolerance is the Orthodox Christianity. It has a long history in Kazakhstan. The foundation for tolerance in the teachings of early Christian apologists was the Logos concept, the Word of God that exists in three principal formsincarnated, spoken, and seeded. The seeded Logos is the human mind; the incarnate Logos (Word of God) is Christ, Christian cult, and the right theology. Christ gives the commandments of love and calls for the perfection in love. "The Christian, in the process of his spiritual maturity, should be freed from the direct opposition of the 'I' and not 'I,' to receive a sensation or consciousness of one's inner unity" (Fedorov, 2003: 107).

In Christian teachings, the essence of unity is expressed in mutual love of believers, "that the love wherewith Thou hast loved Me may be in them, and I in them" (John 17:26 Cross References). The Metropolitan Anthony writes, "That love that reaches out the peril of communing life and willingness to sacrifice it, is the commandment, which been fulfilled brings us into unity with Christ" (Khrapovitskiy, 2009: 27). "Being perfectly filled with the blessed love is the feature that distinguishes a natural human state from the revived condition, which differs Christ's disciples from the world,... the mysterious blessed unity is revealed to the believers in the mutual love and love to Christ..." (Khrapovitskiy, 2009: 27).

These basic principles of the Christian idea of religious tolerance are represented in the activities of two Christian denominations in Kazakhstan, the Orthodox Church, and the Catholic Church. These faith traditions hold the second place after Islam in the number of believers. The Orthodox Church has 295 church buildings (please see, Figure 2 for a glimpse of 
the presence of Russian Orthodox Church in Kazakhstan); and 329 religious associations operate in the Republic, including the Metropolitan District and nine dioceses. The most significant number of Orthodox communities is registered in Almaty region, Akmola region, East Kazakhstan region, North Kazakhstan region, Kostanai region, and Karaganda region. There are some Christian Orthodox monasteries in Kazakhstan. Almost all churches and prayer houses have parish

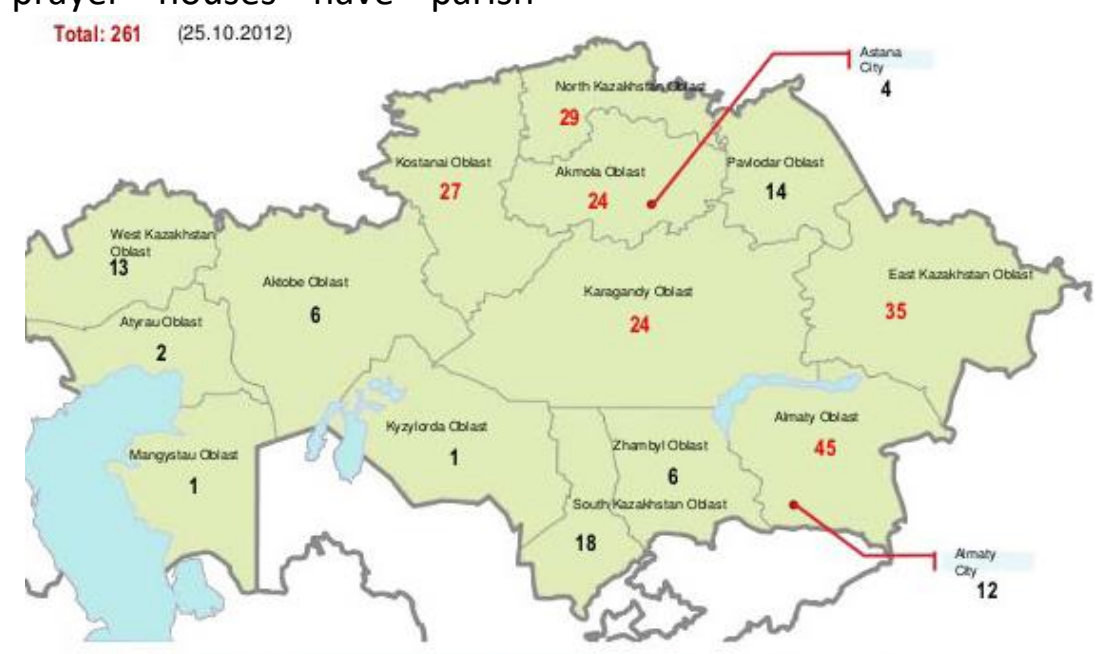

Figure 2: The Presence of Russian Orthodox Church in Kazakhstan Source: Courtesy of the Authors

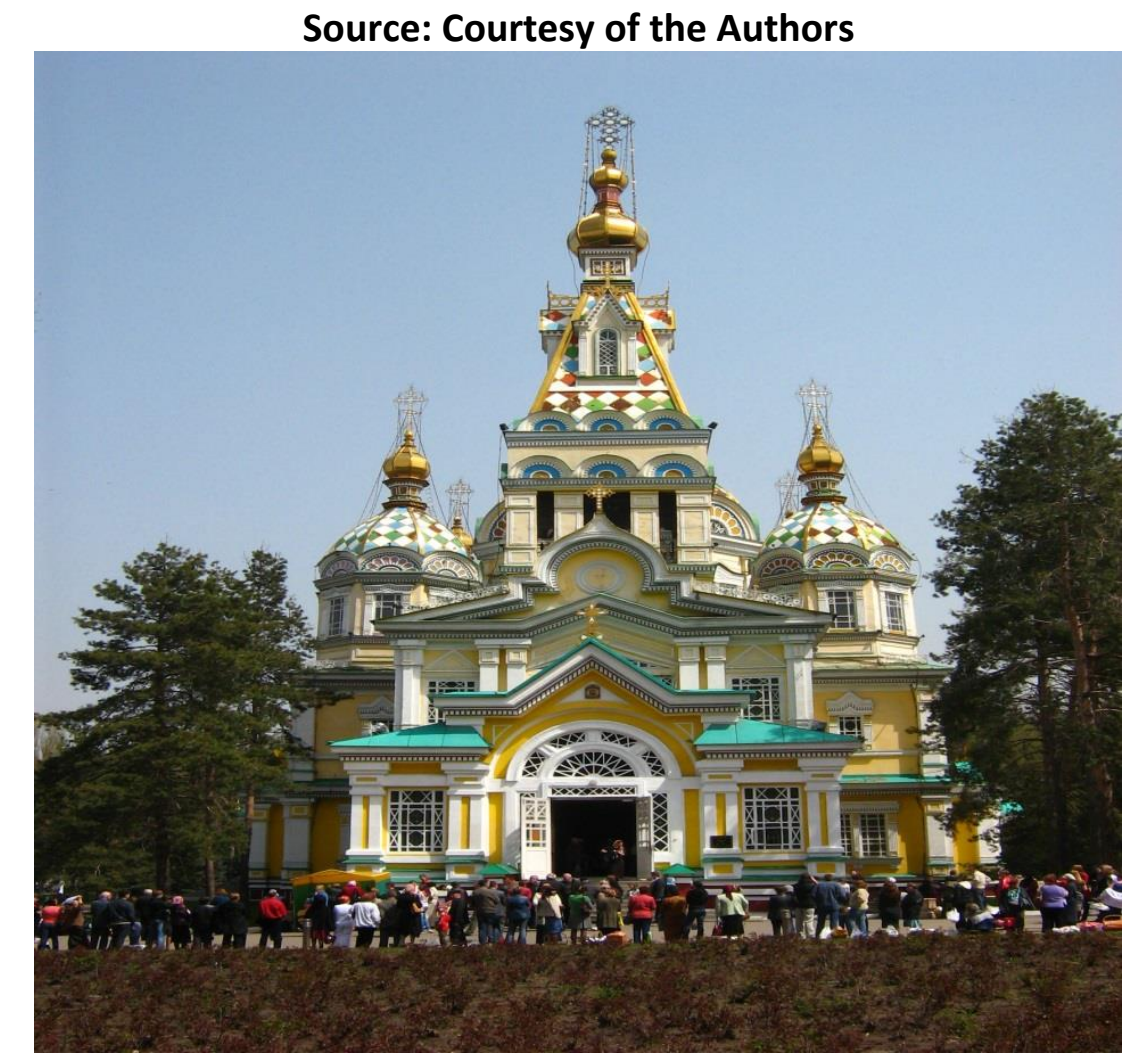

Figure 3: The Ascension Cathedral in Almaty

Source: Courtesy of the Authors schools to teach the fundamentals of the orthodoxy and Sunday schools to edify children and adults. The Eastern Orthodox Christmas on 7 January was included into official state holidays in Kazakhstan.

In 1995, the state handed on the Ascension Cathedral in Almaty to the Orthodox Church. The cathedral was built at the beginning of the 20th century and was recognised as the unique architectural monument (see, Figure 3). 
The 1990s was the period when other cathedrals and temples in different cities of Kazakhstan were returned to the Christian communities. The state patronises the restoration of old religious buildings and the construction of new churches and houses of worship. In recent years, some buildings were constructed such as the Cathedral of Christ, the Saviour in Almaty, the Cathedral of the Annunciation in Pavlodar, Seraphim-Iviron Cathedral in Ekibastuz, St. John the Evangelist Cathedral in Taldykorgan, St. Nicholas' Temple in Satpayev and many others. Several monasteries were also opened. In June 2005 in Astana, the ceremony to dedicate the 150th anniversary of opening and consecrating of Constantine and Yelena Cathedral was held (Voznesenskiy Kafedral'nyy Sobor Almaty). Kazakhstan supports the Orthodox Church on the international level. Thus, the Republic contributed to the restoration of the Temple of Christ, the Saviour in Moscow by gifting granite from the Kordai deposits for furnishing the temple walls.

In January 2010, the Patriarch of Moscow and all Russia Kirill visited Kazakhstan. The head of the Russian Orthodox Church came to Almaty and Astana, met with some officials, and led religious services in the temples. The pinnacle of the visit was the consecration of the Cathedral of the Holy Dormition in the capital of Kazakhstan.

In recent years, the structural reform of the Orthodox Church was implemented in Kazakhstan. In May 2003, the Holy Synod of the Russian Orthodox Church decided on the establishment of the Metropolitan district that included Astana, Ural, and Shymkent dioceses of the Republic. A metropolitan district is a unique form of dioceses association, existing within the framework of the Russian Orthodox Church only in Kazakhstan. The Metropolitan district was created to coordinate religious, educational, publishing and other activities of the dioceses on the territory of the Republic. During 2003-2010, the Metropolitan Methodius (Nemtsov) was the head of the district, and in 2010 the Metropolitan of Astana and
Kazakhstan Alexander (Mogilev) was appointed in his stead.

In July 2010, the Holy Synod of the Russian Orthodox Church adopted a series of documents that define the status of Kazakhstan's metropolis as a new canonical subdivision of the Russian Orthodox Church, the Metropolitan District in the Republic of Kazakhstan (Kazakhstan Orthodox Church), which has much autonomy rights.

In 2010 the Holy Synod of the Russian Orthodox Church decided to open a seminary in Almaty. It is the first higher theological educational institution of the Orthodox Church because previously there was only a religious school. Almaty Seminary has two departments, the pastoral and the regent, where one could do full-time or part-time education. The curriculum included the study of the Scriptures and the liturgy, Homiletics, Church History, Dogmatic, Russian, English and Kazakh languages, Kazakhstan history and other disciplines.

On 29 May 2012, the building of the Synod of Kazakhstan Orthodox Church and the spiritualcultural-educational centre named after the Equal-to-the-Apostles Cyril and Methodius were opened in Astana (Voznesenskiy Kafedral'nyy Sobor Almaty). The Orthodox Church is a regular participant in the interreligious and inter-civilisational dialogue in the country. Her representatives actively take part in forums, conferences, and roundtables at various levels. High-level delegations represented the Russian Orthodox Church at all five Congresses of Leaders of World and Traditional Religions in Astana. In 2012, the Patriarch of Moscow and all Russia Kirill arrived at the capital of Kazakhstan to participate in the work of the 4 th Congress.

From the first steps of independent Kazakhstan, the Russian Orthodox Church and her metropolitan district in the Republic of Kazakhstan, in particular, has been become a reliable partner of the state to strengthen interfaith peace and stability in the society. The Orthodox Church is actively involved in 
different social activities such as the celebration of a national holiday - Nauryz or the Day of Unity of the People of Kazakhstan, conducting art classes in the orphanages, holding art exhibitions and different charitable events (Voznesenskiy Kafedral'nyy Sobor Almaty).
The Roman Catholic Church (RCC) (see, Figure 4) too makes a positive contribution to the preservation of religious tolerance among the believers. In 1991, Pope John Paul II established the Apostolic Administration in Kazakhstan and Central Asia.

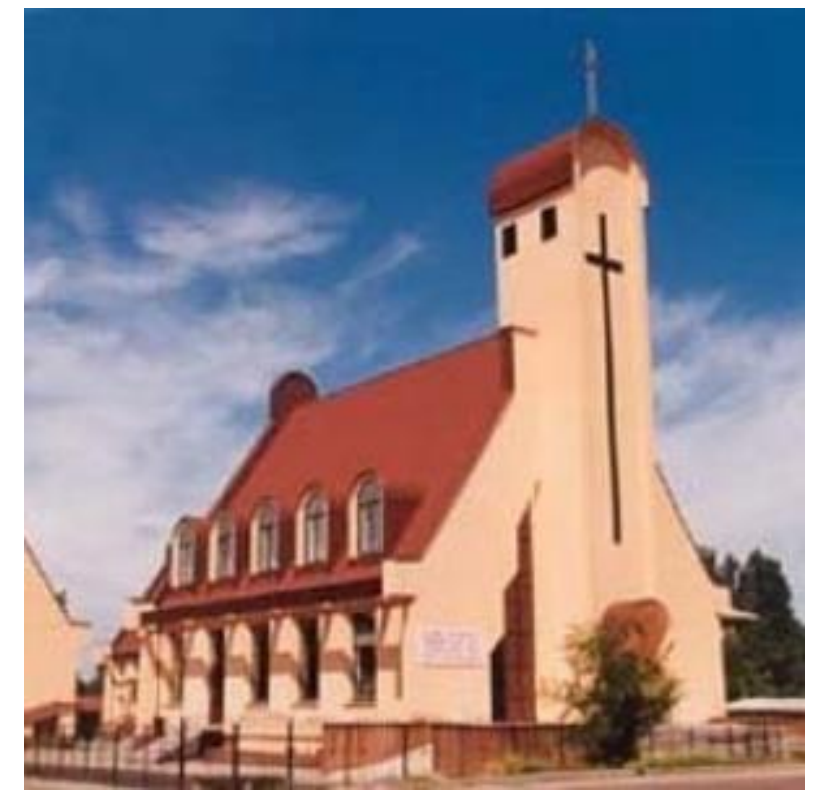

Figure 4: The Roman-Catholic Church of the Holy Trinity in Almaty

In 1997, the parishes of the Central Asian republics were withdrawn from the jurisdiction of the Apostolic Administration of Kazakhstan and received the status of "suijuris", that is, autonomy. In 1999, the Kazakhstan Apostolic Administration was divided into Karaganda Diocese and three new apostolic administrations- Astana, Atyrau, and Almaty. Such administration structures are unusual for the Holy See and had to be replaced by dioceses and archdioceses. Therefore, in May 2003 Pope John Paul II elevated the Apostolic Administration in Astana to the Archdiocese and named it as the Archdiocese of the Blessed Virgin Mary in Astana, chaired by the Archbishop Tomasz Pat. The Archdiocese unites the parishes in Astana, Akmola, Kostanay, North Kazakhstan and Pavlodar regions.

In May 2003, by the Decree of the Pope, a metropolitanate was formed, headed by the first Metropolitan Archbishop Tomasz Pat, and the charter of the Bishops' Conference of Kazakhstan was approved. On 3 October 1994, the State of Vatican and the Republic of Kazakhstan signed the agreement. That day, the Ambassador of Vatican, Apostolic Nuncio, arrived in Almaty. In 1998, the concordat Agreement on the relations between the Republic of Kazakhstan and the Holy See was signed (Rimsko-katolicheskiy kafedral'nyy sobor Presvyatoy Troitsy). Currently, the Catholic Church has 84 communities of believers in the Republic, two archbishops (one is in the post of Metropolitan), three bishops and over 60 priests. There are more than 30 male and female monastic congregations with over 154 monks and nuns. Moreover, the members of the Prelature of Opus Dei have been ministering in the Republic since 1997. The churches hold worship ceremonies in Russian, Ukrainian, German, English and Polish languages. The ethnic composition of the believers is expanding. New church buildings are being constructed in Astana, Almaty, Atyrau, Pavlodar, Karaganda, and other cities.

In 1995, Archbishop Jan Paul Lenga announced that the village Ozernoye in Kellerovskiy district of North-Kazakhstan region to become a Republican sanctuary of the Blessed Virgin Mary of the Queen of the World. An essential 
moment in the activity of the Catholic Church happened in 1998 near that village on the hill Ahimbettau when the monument was opened to the victims of Soviet repression in the form of a twelve-meter cross (Rimsko-katolicheskiy kafedral'nyy sobor Presvyatoy Troitsy).

In 1998, the Interdiocesan Seminary of Maria, the Mother of the Church was launched in Karagandy. It is the only Catholic seminary in Kazakhstan and Central Asia and in May 2006 it had the first graduation of the students.

In June 2000, in Karaganda, the First AllKazakhstan Catholic meeting was organised to celebrate the significant anniversary of the Catholic Church. Within three days, approximately 3.5 thousand people prayed together and participated in the cultural program. Apart from the laity, Kazakhstani and foreign priests and monks took part in the meeting. In August 2000, more than 100 young Catholics from Kazakhstan made the pilgrimage to Rome to meet with the Pope and take part in the World Youth Day.

In 2000, in the city of Schuchinsk of Astana Archdiocese was established under the nameFaith and Reason centre to conduct prayer meetings, spiritual activities, conferences, and other activities. There are some living rooms, a chapel, and a dining room in the centre.

The historically significant outcome of the meetings of Nursultan Nazarbayev, the President of Kazakhstan, and the Pope was the Agreement on Mutual Cooperation signed between the government of Kazakhstan and the Holy See on 24 September 1998, which was ratified on 30 July 1999. President Nazarbayev was the first among the former Soviet Union countries' leaders who took such a political step. Following this agreement, the Pope John Paul II visited the Republic on 22-25 September 2001, and Kazakhstan became the 127th country which he visited during his pontificate. During his visit, the Pope rewarded President Nazarbayev with the order of Pius, the highest award, which was received only by 15 political leaders in the world.
Also in Kazakhstan, there are five registered communities of the Ukrainian Greek Catholic Church in Astana, Pavlodar, Satpayev, Karagandy, and the village Schederty of Pavlodar region that holds services in Ukrainian.

Among the significant events in the religious life of the Catholics was the celebration of 12th anniversary of the Greek Catholic community established in Pavlodar that took place in the parish of Saints Peter and Paul on 12 July 2015. It was attended by Vasiliy Gover, the head of the Greek Catholic Church in Central Asia and Kazakhstan, by senior priests of Astana and Karaganda parishes, the government representatives, leaders of the Ukrainian national and cultural centre in Pavlodar region and by parishioners (Rimsko-katolicheskiy kafedral'nyy sobor Presvyatoy Troitsy).

The Catholic Church actively participates in the Congresses of World Religions in Astana, which is attended by representatives of the Vatican, and local Catholic Church in Kazakhstan, in inter-religious meetings, roundtables, and conferences organised by the governmental institutions in different cities and regions. In the meetings, the representatives of the Church focus on enhancing the general awareness of the need for the culture of peace and harmony as a basis for a prosperous future of the country. The lack of tolerance is considered as a manifestation of ignorance, selfishness or pride. The Church organises meetings with the representatives of other religions and Christian denominations to develop respect for them among her parishioners, to help them understand beliefs of other people. Every church leader tries to establish relationships with leaders of other denominations in his territory at the personal level.

The Catholic Church is active in charity which is directed not only to the Catholics or Christians but also to everyone without exception. Traditionally, the philosophy of charity in the Catholic Church was based on seven corporal and seven spiritual works of mercy. The first group includes feeding the hungry, sheltering 
the homeless, clothing the naked, visiting the sick and imprisoned, and burying the dead. The second group consists of instructing the ignorant, counselling the doubtful, admonishing the sinner, forgiving the offender, not repaying evil for evil, comforting the afflicted, and praying for the living and the dead (Rimsko-katolicheskiy kafedral'nyy sobor Presvyatoy Troitsy).

Thus, we can say that the extensive work is carried out in Kazakhstan by representatives of three major religious organisations (SAMK, Orthodox Church, and Roman Catholic Church) in the aspect of preserving and maintaining religious tolerance among the population. Religious tolerance can be defined as forbearance and respect that are demonstrated by adherents of one religion to the followers of other religious community (Akbergen, Karabayeva \& Ismagambetova, 2016; Zolotukhin 1999). Each community maintains its faith and respects the rights of other believers.

\section{Tolerance as a Factor of Stability}

Religious tolerance is the basis of social unity, public security, and internal stability. Tolerance (from lat. tolerantia - endure) means understanding and acceptance of other ideas, thoughts, attitudes, emotional state, faith, actions, traditions; it is an ability to show patience and tenderness. The critical tasks of Islamic, Orthodox Christian and Catholic religious associations include the prevention of intolerance or xenophobia in any form among their believers, the formation of respect to beliefs of different ethnic groups, to national traditions and customs, the non-admission of radicalisation of religious teachings and fundamentalist ideas, opposition to any form of religious extremism and terrorism.

Tolerance, mutual understanding and respect for the religion of others have become a significant unifying factor and condition for the constant development of statehood, ensuring public stability in Kazakhstan (Akbergen, Karabayeva \& Ismagambetova, 2016; Zolotukhin, 1999). The notion of tolerance in the Kazakh language has several meanings such as charity, caring, respect, humanity, compassion, sensitivity, stamina, appeasement, diplomacy, peacekeeping, care, generosity, partnership, hospitality, ability to negotiate, friendliness, harmony in all respects, and the path to peace and harmony (Aubakirova et al., 2016).

Kazakh people attaches particular importance to unity and harmony, appreciate it as a source of existence and essence of life. Such attitude is echoed by the following Kazakh proverbs: "Where you find unity - there you find life," "The beginning of prosperity is the unity," "Wellbeing is in solidarity," "You cannot run a thread through an eyelet unless you join your fingers," etc. The development of unity and harmony in multiethnic Kazakhstan has a particular significance. The ancestors of Kazakh people understood the impossibility of the future without unity, and therefore, they considered this principle as the most important in the upbringing of children. It is transmitted as a valuable heritage from generation to generation up to the present (Aubakirova et al., 2016).

The goals of modern Kazakhstan society are to live in peace with all nations and religions, strengthening faith, avoiding persecution, insult, and humiliation of other people's feelings and beliefs. Taking into consideration the creative potential of religion could help in contributing to the formation of fraternity and peaceful coexistence among nations. From this respective, tolerance gives the possibility of reaching agreement through the dialogue, considering views of all parties.

In the 21st century, the dialogue is one of the principal means of development in all spheres of society, political, economic, cultural, and spiritual. The dialogue provides an opportunity to find optimal ways to solve problems through a discussion. It promotes the development of interpersonal humanitarian relations, as well as the cooperation of religious organisations. That is why the representatives of all religions should support the development of interreligious dialogue and strengthen interethnic consent. The building of a civilised 
society and creating the right perception of other cultures and faith traditions without tolerance would be impossible.

The modern society gradually reaches tangible progress in the development of religious tolerance, notwithstanding, the fact that world religions have a high internal call to influence the mass consciousness. Reaching out a peaceful agreement depends on mutual efforts of state, society, and religious leaders who nurture tolerance as a useful tool to achieve public consensus.

The progress and prosperity of modern civilisation could be reached only by creating tolerant relations between representatives of different ethnicities, religions, and cultures. Formation of religious tolerance is a reliable way to ensure secure and peaceful life. Conflicts and clashes that occur in various contexts and lead to intolerance, xenophobia and fanaticism pose a threat to the peaceful coexistence of states, societies, and humanity as a whole.

Nowadays, the appeal to tolerance as a new type of social relationships could lead to the positive solution of emerging religious contradictions and form a new mindset leading to positive changes. "Tolerance, on the one hand, is a canon of humanity that regulates human activities and forms an unusual worldview, on the other hand, it is a practical tool to resolve contradictions and scandalous disputes in a positive way" (Zolotukhin, 1999: 15).

Tolerance starts with the manifestation of mutual respect among neighbours in daily life. In a broader sense, it goes to intercultural, interreligious, interconfessional, interethnic and interlanguage appreciation and esteem. Tolerance is a necessary quality to understand the peculiarities of other cultures and religions. Throughout the world, it includes rejection of violence and domination, support of equality, recognition of the variety of faiths and the diversity of human cultures. Tolerance implies recognition of human rights and freedoms, along with pluralism of opinions, thus, making it one of the fundamental principles of democracy. Tolerance is an indicator of the level of political culture and development of society. The religious tolerance aims at ensuring internal stability and unity in society, and its formation becomes now an urgent task in the modern world.

\section{Conclusion}

After considering the contemporary ethnic and religious situation in modern Kazakhstan, we can make the following concluding observations. The respect of Kazakh people for others' faiths, their tolerance, and mutual understanding has become the primary condition for the sustainable development of the statehood and public stability in the country. Peace, harmony, a dialogue of cultures and religions are promoted in the Republic as fundamental values that follow the world standards. Such institutions as the Assembly of the People of Kazakhstan and the Congress of Leaders of World and Traditional Religions have become unique Eurasian models of the dialogue of cultures and a platform for interfaith dialogue.

Relying on the fact that the main world religions - Christianity, Islam - have similar views on the tolerance issue, they are used for encouraging people to develop mutual understanding, promote spiritual education, and restrain negative emotions and feedback. The cultural dialogue is the best way of nurturing tolerance, including religious and ethnic one.

We demonstrated that religious tolerance is one of the conditions for securing interfaith harmony. Moreover, today the mutual religious respect has become a decisive factor to ensure Kazakhstan's peace, stability, and economic progress. That is why, the government promotes the principle of tolerance as a standard of the political culture of society, one of the fundamental principles of the state policy in interethnic and interconfessional relations.

Each society has two options to keep stability. The first one is to oppress and eliminate all "internal dissent" but keep different views with 
the external structures. Such is the way of the "closed system" to survive. The second option welcomes pluralism and proves to be more viable at the present stage of human social development. D. Truman noted, "Society can avoid a revolution, degeneration, decline and maintain stability only through the multiplicity of elegance" (Truman 1951: 10).

Tolerance in the multiethnic society implies not only the recognition of existing ethnocultural, religious, and confessional differences but also the recognition of "unity in diversity." Then the existing ethnocultural differences would fail to play a significant institutionalising role. Kazakhstan was able to ensure the "unity in diversity" through a shared civic identity. This phenomenon became one of the critical points in the national idea, expressed in the Doctrine of National Unity of Kazakhstan (The Doctrine of National Unity of Kazakhstan, 2010).

Tolerance is focused on dialogue, in which the attitude towards the other as a representative of the total humanity is essential. This strategy helps to move from disagreement and conflict to dialogue and understanding in the name of preserving stability, harmony, and peace in society.

\section{References}

Abdakimov, A. (2009). Identifikatsiya religioznoy situatsii v sovremennom Kazakhstane [Identifying the Religious Situation in Modern Kazakhstan]. In The Problems of Religious Identity in the Context of National Security, International Scientific Conference Materials to the 75th Anniversary of Al-Farabi Kazakh National University. Almaty, 32.

Adorno T. Senford R. N., Frenkel'-Bryunsvik E. and Levinson D. Dzh. (2001). Issledovaniye avtoritarnoy lichnosti [The study of the authoritarian personality]. Moscow: Akademiya issledovaniy kul'tury.

Akbergen A., Karabayeva A.G. and Ismagambetova Z.N. (2016). Tolerance as a Social Value in Contemporary Kazakhstani Society, European Journal of Science and Theology, 12(4): 215-227.
Aubakirova S., Ismagambetova Z.N., Karabayeva A.G., Mirsabekova A.Sh. and Rysbekova Sh.S. (2016). Tolerance as an Ethical Indicator of Kazakh Mentality and Traditional Culture, Global Media Journal, Special Issue: 311 online at http://www.globalmediajournal.com/openaccess/tolerance-as-an-ethical-indicator-ofkazakh-mentality-and-traditional-culture.pdf (accessed 3 March 2018)

\section{Doktrina natsionalnogo edinstva Kazahstana}

[The Doctrine of National Unity of Kazakhstan], April 29, 2010, online at http://www.inform.kz/ru/doktrina-nacionalnogo-edinstva-kazahstana_a2263364 (accessed 28 February 2018)

Duluman, $Y .$, Tolerantnost' $v$ islame, online at //http:// sotref.com/religija/islam (accessed 3 March 2018)

Fitzpatrick, M. (2006). Toleration and the Enlightenment Movement. In Toleration in Enlightenment Europe, (ed. Ole Peter Grell \& Roy Porter), Cambridge: Cambridge University Press.

Fedorov, V. (2003). Mezhkonfessional'nyy dialog i problemy tolerantnosti

[Interconfessional Dialogue and Problems of Tolerance], St. Petersburg: St. Petersburg Philosophical Society.

Gabitov T.H., Karabaeva A.G., and Ismagambetova Z.N. (2015). Faktoryi i osnovaniya religioznoy tolerantnosti $v$ Respublike Kazahstan [Factors and Foundations of Religious Tolerance in the Republic of Kazakhstan]. Almaty: Vestnik KazNU. Religious Studies, 4 (4), 15-23.

Hall E.T. (1990). Understanding Cultural Differences: Germans, French and Americans. Boston: Intercultural Press.

Habermas J. 2006. Kogda my dolzhny byt' tolerantnymi? O konkurentsii videniy mira, tsennostey i teoriy [When should we be tolerant? On the competition of visions of the world, values and theories]. Moscow: Institute of Social Studies of Russian Academy of Science. Sotsis, 1: 45-53. 
Ismagambetova Z.N. and Karabayeva A.G. (2015). Tolerantnost' kak sotsekul'yarnyy fenomen [Tolerance as a Postsecular Phenomenon]. Almaty: Kazak Universiteti Press.

Ismagambetova Z.N., Rysbekova S.S. and Balpanov N. (2016). Toleranttylyktyk, kalyptastyrudyn zholdary [Ways of Building Toleranc], Almaty: Vestnik KazNU. Philosophy, Cultural Studies, Politology. 3 (57): 48-56.

John 17:26 Cross References, online at https://www.openbible.info/labs/crossreferences/search?q=John+17\%3A26 (accessed 28 June 2018)

Kadyrzhanov R. (2013). Mezhetnicheskaya stabil'nost' i natsional'naya konsolidatsiya $v$ Kazakhstane [Interethnic Stability and National Consolidation in Kazakhstan].In The National Consolidation, Round Table Materials, Almaty, 28 March 2013

Khrapovitskiy A.A. (2009). Nravstvennaya ideya dogmata Tserkvi [The Moral Idea of Church Dogma], Moscow: Pravoslavnyy Apologet.

Levi-Strauss K. (2000). Rasa i istoriya [Race and history]. In Put' masok [The way of masks]. Moscow: Respublika, 323-357.

Mansurova A.S. (2015). Religioznaya tolerantnost' i religioznyy dialog v usloviyakh globaliziruyushchey real'nosti. Izvestiya Natsional'noy Akademii nauk Respubliki Kazakhstan [Religious Tolerance and Marcuse H. 2011. Kriticheskaya teoriya obshchestva/ Repressivnaya tolerantnost' [Critical Theory of Society / Repressive Tolerance]. Moscow: Astrel'.

Marshall J. and Locke J. (2006). Toleration and Early Enlightenment Culture, Cambridge:

Cambridge University Press.

Ministry of National Economy of the Republic of Kazakhstan. Committee on statistics Official Website, online at http://stat.gov.kz/faces/publicationsPage/publi cationsOper/homeNumbersPopulation/publBul IS14-

2016?_afrLoop=1972794742117533\#\%40\%3F afrLoop\%3D1972794742117533\%26_adf.ctrl-
state\%3D17glwssppt_84 (accessed 20 June 2018)

Mendus S. (1989). Toleration and the Limits of Liberalism. London: Humanities Press International.

Muratbekov E.B. (ed.) (2015). Religioznye ob'edineniya $v$ Kazakhstane: handbook.[Religious associations in Kazakhstan]. Astana: International Centre of Cultures and Religions.

Nicholson P. (1985). Toleration as a Moral Ideal. Aspects of Toleration. In J. Horton, S. Mendus (Eds.). Aspects of Toleration, London, New York: Methuen and Co. Ltd.

Nysanbayev A.N. (2007). Gumanisticheskiy potentsial filosofskogo obrazovaniya [Humanistic potential of philosophical education]. Al'-Farabi, 4 (20), 5.

On Religious Activities and Religious Associations. 15.10.2011. Kazahstanskaja Pravda, No. 330-331 (15.10.2011), 26721 26722

Press-tsentr DUMK po Taldykorganskomu region, online at http:// www.muftyat.kz (accessed 3 March 2018)

Religious Dialogue in the Context of Globalizing Reality. Proceedings of the National Academy of Sciences of the Republic of Kazakhstan. Seriya obshchestvennykh i gumanitarnykh nauk. 1: 117-122.

Religioznyye ob yedineniya $v$ Respublike Kazakhstan [Religious Associations in the Republic of Kazakhstan]. 2012. Astana: Agency of the Republic of Kazakhstan for Religious Affairs.

Rimsko-katolicheskiy kafedral'nyy sobor Presvyatoy Troitsy, online at http: //fime.sc/sights (accessed 3 March 2018)

Sultangaliyeva, A. (2013). Religioznaya identichnost' i natsional'naya integratsiya v Kazakhstane [Religious Identity and National Integration in Kazakhstan]. In The National Consolidation, Round Table Materials. Almaty, 28 March 2013 
Tashbulatova, M. (2013). Osnovaniya i printsipy mezhreligioznogo dialoga [Bases and Principles of Interreligious Dialogue]. In The Influence of Religion on Modern Society, International Scientific Conference Materials, Almaty: IFPR KN MON RK.

The Holy Bible, online at https://www.biblegateway.com/passage/?sear ch=John+13\&version=NIV (accessed 19 June 2018)

The Universal Declaration of Human Rights. The United Nations Official Website, online at http://www.un.org/en/universal-declarationhuman-rights (accessed 10 March 2018)

The Holy Qur'an, online at https://quran.com/ (accessed 11 March 2018)

The Official Website of the Spiritual Administration of Muslims of Kazakhstan, online at www.muftyat.kz (accessed 11 March 2018)
Truman D.B. (1951). The Governmental Process: Political Interests and Public Opinion, New York: Knopf.

Voznesenskiy Kafedral'nyy Sobor Almaty, online at http://cafedral@mitropolia.kz (accessed 11 March 2018)

Walzer, M. (2000). O terpimosti [On Tolerance]. Perevod s angl. yaz. I. Myurnberg. Moscow: Ideya-Press, Dom intellektual'noy knigi.

Williams B. (1996). Toleration: An Impossible Virtue? Providence, RI: Berghahn,

Williams B. (2000). Tolerating the Intolerable. Durham: Duke Univ. Press

Zolotukhin V.M. (1999). Dve kontseptsii tolerantnosti [Two Concepts of Tolerance], Kemerovo: Kuzbass Technical University.

Zolotukhin V.M. (2006). Tolerantnost' kak problema filosofskoy antropologii [Tolerance as a Problem of Philosophical Anthropology], Yekaterinburg: Ural State University. 